\title{
A new species of Hyphessobrycon Durbin from northeastern Brazil: evidence from morphological data and DNA barcoding (Characiformes, Characidae)
}

\author{
Erick Cristofore Guimarães ${ }^{1,5}$, Pâmella Silva De Brito ${ }^{2,5}$, Leonardo Manir Feitosa ${ }^{3}$, \\ Luís Fernando Carvalho-Costa ${ }^{4}$, Felipe Polivanov Ottoni ${ }^{1,2,5,6}$
}

I Universidade Federal do Maranhão, Programa de Pós-Graduação em Biodiversidade e Conservação. Av. dos Portugueses 1966, Cidade Universitária do Bacanga, CEP 65080-805, São Luis, MA, Brazil 2 Universidade Federal do Maranhão, Programa de Pós-Graduação em Biodiversidade e Biotecnologia da Amazônia Legal. Av. dos Portugueses 1966, Cidade Universitária do Bacanga, CEP 65080-805, São Luis, MA, Brazil 3 Universidade Federal de Pernambuco, Programa de Pós-Graduação em Biologia Animal. Av. Professor Moraes Rego 1235, Cidade Universitária, CEP: 50670-901, Recife, PE, Brazil 4 Universidade Federal do Maranhão, Departamento de Biologia, Laboratório de Genética e Biologia Molecular, Av. dos Portugueses 1966, Cidade Universitária do Bacanga, CEP 65080-805, São Luis, MA, Brazil 5 Universidade Federal do Maranhão, Laboratório de Sistemática e Ecologia de Organismos Aquáticos, Centro de Ciências Agrárias e Ambientais, Campus Universitário, CCAA, BR-222, KM 04, S/N, Boa Vista, CEP 65500-000, Chapadinha, MA, Brazil 6 Universidade Federal do Maranhão, Programa de Pós-Graduação em Oceanografia. Av. dos Portugueses 1966, Cidade Universitária do Bacanga, CEP 65080-805, São Luís, MA, Brazil

Corresponding author: Erick Cristofore Guimaräes (erick.ictio@yahoo.com)

Academic editor: J. Maldonado | Received 3 February 2018 | Accepted 7 May 2018 | Published 7 June 2018

http://zoobank.org/07277DB7-7563-4712-AC3F-E940B1B4AC27

Citation: Guimarães EC, De Brito PS, Feitosa LM, Carvalho-Costa LF, Ottoni FP (2018) A new species of Hyphessobrycon Durbin from northeastern Brazil: evidence from morphological data and DNA barcoding (Characiformes, Characidae). ZooKeys 765: 79-101. https://doi.org/10.3897/zookeys.765.23157

\begin{abstract}
A new species of Hyphessobrycon is described for the upper Munim and Preguiças river basins, northeastern Brazil, supported by morphological and molecular species delimitation methods. This new species belongs to the Hyphessobrycon sensu stricto group, as it has the three main diagnostic character states of this assemblage: presence of a dark brown or black blotch on the dorsal fin, absence of a black midlateral stripe on its flank and the position of Weberian apparatus upward horizontal through dorsal margin of operculum. Our phylogenetic analysis also supported the allocation of the new species in this group; however, it was not possible to recover the species sister-group. Pristella maxillaris and Moenkhausia hemigrammoides were recovered as the sister-clade of the Hyphessobrycon sensu stricto group.
\end{abstract}

Copyright Erick Cristofore Guimarães et al. This is an open access article distributed under the terms of the Creative Commons Attribution License (CC BY 4.0), which permits unrestricted use, distribution, and reproduction in any medium, provided the original author and source are credited. 


\section{Resumo}

Uma nova espécie de Hyphessobrycon é aqui descrita para as bacias do alto Rio Munim e Preguiças, nordeste do Brasil, sustentada por métodos morfológicos e moleculares de delimitação de espécies. Essa nova espécie é membro do grupo Hyphessobrycon sensu stricto, já que possui os três principais estados de caracteres diagnósticos desse agrupamento: presença de uma mancha marrom escura ou negra na nadadeira dorsal, ausência de uma faixa lateral no meio do flanco e a posiçáo do aparelho de Weber localizado acima da horizontal da margem dorsal do opérculo. Nossa análise filogenética também apoia o posicionamento da nova espécie dentro desse grupo, entretanto não foi possível recuperar o grupo-irmão da espécie. Pristella maxillaris e Moenkhausia hemigrammoides foram recuperados com sendo o clado irmáo do grupo Hyphessobrycon sensu stricto.

\section{Keywords}

Hyphessobrycon sensu stricto, integrative taxonomy, Pristellinae, rosy tetra clade

\section{Palavras-chave}

clado rosy tetra, Hyphessobrycon sensu stricto, taxonomia integrativa, Pristellinae

\section{Introduction}

Hyphessobrycon Durbin, 1908 is one of the most species-rich genera of Characidae, currently comprising approximately 150 valid species (Ohara et al. 2017). It is widely distributed along the river basins of the Neotropical region, from southern Mexico to the La Plata River basin in northeastern Argentina (Carvalho and Malabarba 2015, Teixeira et al. 2015, Garcia-Alzate et al. 2017), with highest diversity in the Amazon basin (Miquelarena and López 2006, Lima et al. 2013, Bragança et al. 2015, Carvalho and Malabarba 2015, Marinho et al. 2016, Carvalho et al. 2017, Moreira and Lima 2017).

Extensive data show that Hyphessobrycon is not a monophyletic group (Carvalho et al. 2017, Moreira and Lima 2017). It was diagnosed by an artificial combination of character states proposed by Eigenmann (1917), such as: the presence of an adipose fin; maxillary with few teeth or none; lateral line incomplete; third infraorbital bone not in contact with the sensory canal of the preopercle; premaxillary with two series of teeth; and caudal-fin lobes without scales at the base. Nevertheless, new species descriptions continue to follow this artificial combination (e.g., Ohara et al. 2017, Garcia-Alzate et al. 2017, Carvalho et al. 2017, Moreira and Lima 2017).

In addition, some artificial species groups of Hyphessobrycon were proposed based on the combination of character states (e.g., Weitzman and Palmer 1997, Zarske 2014, García-Alzate et al. 2008a, b, 2013, Carvalho and Malabarba 2015) relying mainly on coloration patterns. However, in many cases, it is not possible to assign without reasonable doubt to which group a particular species belongs (Bragança et al. 2015).

One of this species group was termed as "group F" by Géry (1977), being defined by the presence of a dark brown or black blotch on dorsal fin and no midlateral stripe on body. This group was previously termed as "callistus group", with a similar composition and definition by Géry (1961). Weitzman and Palmer (1997) proposed the name "rosy tetra clade" for this assemblage, including approximately 30 species of Hyphessobrycon 
and a few other probably closely related species belonging to other genera. These authors also confirmed the presence of the black blotch on the dorsal fin as one of the main diagnostic features of this assemblage. However, they also stated that this blotch was absent in some of its species (e.g., H. ecuadoriensis Eigenmann \& Henn, 1914, H. loweae Costa \& Géry, 1994 and H. panamensis Durbin, 1908).

After that, Carvalho (2011) and Carvalho and Malabarba (2015) proposed the group named Hyphessobrycon sensu stricto, diagnosed by the position of Weberian apparatus upward horizontal through dorsal margin of operculum, presence of a black blotch on dorsal fin and the absence of a midlateral black stripe on body, with a more restricted composition than the "rosy tetra clade" sensu Weitzman and Palmer (1997), comprising: H. compressus (Meek, 1904), H. bentosi Durbin, 1908, H. copelandi Durbin, 1908, H. epicharis Weitzman \& Palmer, 1997, H. eques (Steindachner, 1882), H. erythrostigma (Fowler, 1943), H. georgettae Géry, 1961, H. haraldschultzi Travassos, 1960, H. hasemani Fowler, 1913, H. khardinae Zarske, 2008, H. megalopterus (Eigenmann, 1915), H. micropterus (Eigenmann, 1915), H. minor Durbin, 1909, H. pulchripinnis Ahl, 1937, H. pyrrhonotus Burgess, 1993, H. rosaceus Durbin, 1909, H. roseus (Géry, 1960), H. simulatus (Géry, 1960), H. socolofi Weitzman, 1977, H. sweglesi (Géry, 1961), H. takasei Géry, 1964 and H. werneri Géry \& Uj, 1987. Other species recently referred to the "rosy tetra clade" such as Hyphessobrycon dorsalis Zarske, 2014, H. jackrobertsi Zarske, 2014, H. paepkei Zarske, 2014 and H. pando Hein, 2009 share these traits, but their taxonomic status is uncertain (Carvalho and Malabarba 2015). The key point is that the remaining species of Hyphessobrycon included in the other groups will probably need to be assigned to other genera or new genera (Hyphessobrycon sensu lato) (Carvalho and Malabarba 2015).

One way to overcome the confusing taxonomy of problematic groups, to have accurate species identifications and species diversity estimates of groups is to use different operational criteria for species delimitation (Goldstein and Desalle 2010, Padial et al. 2010). Any operational criteria (species delimitation methods) may separately provide evidence about the species limits and identity independently from other criteria (de Queiroz 2005, 2007), but evidence corroborated from multiple operational criteria is considered to produce stronger hypotheses of lineage divergence (de Queiroz 2007, Goldstein and Desalle 2010), converging to the proposal for an integrative taxonomy (Goldstein and Desalle 2010, Padial et al. 2010). Gathering morphological and molecular data has become a common practice to identify and delimit species of fish (Teletchea 2009), mainly in groups including cryptic or morphologically similar species. The most widespread molecular method used in taxonomy has been the DNA barcoding, which consists on the use of a single gene from mitochondrial DNA (cytochrome oxidase subunit I - COI) as a proxy for species differentiation (Hebert et al. 2003). In fact, several studies have been carried out using molecular markers and new species have been delimited and/or described, in most cases, based both on molecular and morphological evidence (e.g., Costa and Amorim 2011, Costa et al. 2012, Roxo et al 2012, Villa-Verde et al. 2012, Castro-Paz et al. 2014, Costa et al. 2014, Benzaquem et al 2015, Mattos et al. 2015, Costa et al. 2017). 
A new species of Hyphessobrycon, member of the Hyphessobrycon sensu stricto Carvalho and Malabarba, 2015 is herein described from the Munim and Preguiças river basins, two coastal river basins of the Maranhão State, northeastern Brazil, based on both morphology and molecular data.

\section{Materials and methods}

\section{Morphological analysis}

Measurements and counts were made according to Fink and Weitzman (1974), with exception for the scale rows below lateral line, which were counted to the insertion of pelvic fin. Horizontal scale rows between the dorsal-fin origin and lateral line do not include the scale of the median predorsal series situated just anterior to the first dorsalfin ray. Counts of supraneurals, vertebrae, procurrent caudal-fin rays, unbranched dorsal and anal fin rays, branchiostegal rays, gill-rakers, premaxillary, maxillary, and dentary teeth were taken only from cleared and stained paratypes $(\mathrm{C} \& \mathrm{~S})$, prepared according to Taylor and Van Dyke (1985). The four modified vertebrae that constitute the Weberian apparatus were not included in the vertebra counts and the fused PU1 + U1 was considered as a single element. Osteological nomenclature follows Weitzman (1962). Institutional abbreviations follow Sabaj-Pérez (2016), with addition of CICCAA Coleção Ictiológica do Centro de Ciências Agrárias e Ambientais and CPUFMA Coleção de Peixes da Universidade Federal do Maranhão.

\section{Comparative material examined}

All specimens are from Brazil.

Hyphessobrycon amandae Géry \& Uj, 1987: UFRJ 1557, 5 spcms, Goiás State, Jussara municipality. $\boldsymbol{H}$. bentosi: CICCAA 00849, 2 spcms, aquarium trade. $\boldsymbol{H}$. cf. bentosi: CICCAA 00701, $1 \mathrm{spcm}$, Pará State, Paragominas municipality. CICCAA 00702, 2 spcms, Pará State, Paragominas municipality. CICCAA 00703, 1 spcm (C\&S), Pará State, Paragominas municipality. H. bifasciatus Ellis, 1911: UFRJ 0068, 6 spcms, Espírito Santo State, Marataízes and Guarapari municipality. H. copelandi: CICCAA 00722, 2 spcms, Pará State, Marabá municipality. H. diancistrus Weitzman, 1977: UFRJ 2166, 55 spcms, Tocantins State, Ilha do Bananal municipality. $\boldsymbol{H}$. eques: CICCAA 00715, $4 \mathrm{spcms}$ (C\&S), Minas Gerais State, Tombos municipality. CICCAA 00710, 51 spcms, Minas Gerais State, Tombos municipality. H. griemi Hoedeman, 1957: UFRJ 4496, 7 spcms, Santa Catarina State, Esplanada municipality. $\boldsymbol{H}$. haraldschultzi: CICCAA 00873, 20 spcms, Tocantins State, Ilha do Bananal municipality. H. itaparicensis Lima \& Costa, 2001: CICCAA 00314, 6 spcms, Sergipe State, Areia Branca municipality. Pristella maxillaris (Ulrey, 1894): CICCAA 00850, 2 spcms, aquarium trade. H. micropterus: FMNH 57916, 
$1 \mathrm{spcm}$, Rio São Francisco at Lagoa do Porto (Photograph of a Holotype). CICCAA 00300, 24 spcms, Bahia; Barras municipality. CICCAA 00699, 8 spcms (C\&S), Barras, Bahia municipality. H. reticulatus Ellis, 1911: UFRJ 0107, $4 \mathrm{spcms,} \mathrm{Rio} \mathrm{de} \mathrm{Janeiro}$ State, Desengano municipality. H. sergipanus Bragança, Ottoni \& Rangel-Pereira, 2016: CICCAA 00296, 11 spcms, Sergipe State, Estância municipality. UFRJ 5582, 8 spcms, Mato Grosso State, Poconé municipality. UFRJ 3937, 4 spcms, Mato Grosso State, Cárceres municipality. H. stegemanni Géry, 1961: UFRJ 1988, 17 spcms, Tocantins State, Porto Nacional municipality. H. sweglesi: CICCAA 00852, $2 \mathrm{spcms,}$ trade aquarium. $\boldsymbol{H}$. wernerei: MUZUSP 42365, $1 \mathrm{spcm}$, Pará State, Santa Maria do Pará municipality. CICCAA 00751, $1 \mathrm{spcm}$, Pará State, Paragominas municipality.

\section{DNA extraction, amplification, and sequencing}

DNA extraction was carried out with the Wizard Genomic DNA Purification kit (Promega) following manufacturer's protocol. DNA quality was evaluated by agarose gel electrophoresis stained with GelRed (Biotium) and was quantified using Nanodrop 2000 (Thermo Fisher Scientific). DNA was stored at $-20^{\circ} \mathrm{C}$ until further procedures. Samples $(\mathrm{N}=4$; Table 1$)$ were amplified using standard PCR (Polymerase Chain Reaction) for partial cytochrome oxidase subunit 1 (COI) gene, with primers designed by Ward et al. (2005) (FISHF1 5'-TCAACCAACCACAAAGACATTGGCAC-3' and FISHR1 5'-TAGACTTCTGGGTGGCCAAAGAATCA-3'). Amplification reactions were performed in a total volume of $15 \mu \mathrm{l}$ comprising $1 \times$ buffer, $1.5 \mathrm{mM} \mathrm{MgCl}_{2}, 200$ $\mu \mathrm{M}$ dNTP, $0.2 \mathrm{uM}$ of each primer, $1 \mathrm{U}$ of Taq Polymerase (Invitrogen), $100 \mathrm{\eta g}$ of DNA template, and ultrapure water. The amplification program consisted of a denaturation of $2 \mathrm{~min}$ at $94^{\circ} \mathrm{C}$, followed by 35 cycles of 30 s at $94^{\circ} \mathrm{C}, 30$ s at $54^{\circ} \mathrm{C}$, and $1 \mathrm{~min}$ at $72{ }^{\circ} \mathrm{C}$, ending in an extension phase of $10 \mathrm{~min}$ at $72{ }^{\circ} \mathrm{C}$. Amplicons were visualized in $1 \%$ agarose gel electrophoresis stained with GelRed (Biotium) and purified with Illustra GFX PCR DNA and Gel Purification Kit (GE Healthcare). Samples were sequenced using both forward and reverse primers and BigDye Terminator kit 3.1 Cycle Sequencing kit (Thermo Fisher Scientific) in ABI 3730 DNA Analyser (Thermo Fisher Scientific) Consensus sequences were edited in Geneious 9.0.5 (Kearse et al. 2012) and aligned using ClustalW (Thompson 1994) with those from Hyphessobrycon species available in Barcode of Life Database (BOLD) and Genbank (NCBI-National Center for Biotechonology Information) (accession numbers are in Table 1).

\section{Species concept, species delimitation, and diagnoses}

The unified species concept (de Queiroz 2005, 2007) is herein adopted by expressing the conceptual definition shared by all traditional species concepts - "species are (segments of) separately evolving metapopulation lineages" - when operational criterion elements to delimit taxa are excluded from the concepts. According to this concept, 
Table I. Sampling sites, specimens and DNA sequence information included in the study.

\begin{tabular}{|c|c|c|c|c|c|}
\hline Species & Locality & $\begin{array}{c}\text { Basin/ } \\
\text { drainage }\end{array}$ & Country & $\begin{array}{c}\text { GenBank/ } \\
\text { BoldSystems }\end{array}$ & Catalog number \\
\hline Hyphessobrycon piorskii sp. $\mathrm{n}$. & Anapurus, Maranhão & Munin & Brazil & MF765796 & CICCAA00725 \\
\hline Hyphessobrycon piorskii sp. n. & Anapurus, Maranhão & Aunim & Brazil & MF765797 & CICCAA00726 \\
\hline Hyphessobrycon piorskii sp. n. & Barreirinhas, Maranhāo & Preguiças & Brazil & MG791915 & CICCAA01650 \\
\hline Hyphessobrycon piorskii sp. $\mathrm{n}$. & Anapurus, Maranhão & Munim & Brazil & MG791914 & CICCAA01651 \\
\hline Hyphessobrycon bentosi & Barcelos, Amazonas & Negro & Brazil & HYP097-13 & INPA37684-5939 \\
\hline Hyphessobrycon bentosi & Barcelos, Amazonas & Tegro & Brazil & HYP098-13 & INPA37684-5940 \\
\hline Hyphessobrycon bentosi & Barcelos, Amazonas & Negro & Brazil & HYР099-13 & NPA37684-5942 \\
\hline Hyphessobrycon bentosi & Barcelos, Amazonas & Negro & Brazil & HYP100-13 & INPA37684-5943 \\
\hline Hyphessobrycon bentosi & Manaus, Amazonas & - & Brazil & HYP116-13 & 7-BA1 \\
\hline Hyphessobrycon bentosi & Manaus, Amazonas & - & Brazil & HYP117-13 & INPA39527-BA2 \\
\hline Hyphessobrycon bentosi & Manaus, Amazonas & - & Brazil & HYP118-13 & INPA39527-BA3 \\
\hline Hyphessobrycon bentosi & Manaus, Amazonas & - & Brazil & HYP119-13 & BA4 \\
\hline Hyphessobrycon copelandi & Tabatinga, Amazonas & Solimôes & Brazil & HYP094-13 & INPA37683-TU1 \\
\hline Hyphessobrycon copelandi & ga, Amazonas & Solimões & Brazil & HYP095-13 & $3-T U 1$ \\
\hline Hyphessobrycon copelandi & abatinga, Amazonas & Solimões & Brazil & HYP096-13 & TU1 \\
\hline Hyphessobrycon eques & Santarém, Pará & Amazonas & Brazil & НYР070-13 & INPA37678-IC2 \\
\hline Hyphessobrycon eques & Parintins, Amazonas & Amazonas & Brazil & HYP072-13 & 30-AL1 \\
\hline Hyphessobrycon erythrostigma & Tabatinga, Amazonas & Solimões & Brazil & НYР073-13 & NPA37681-AP1 \\
\hline Hyphessobrycon erythrostigma & Tabatinga, Amazonas & Solimões & Bmol & HYP074-13 & NPA37681-AP2 \\
\hline Hyphessobrycon epicharis & $\begin{array}{r}\text { São Gabr } \\
A\end{array}$ & Negro & Brazil & HYP002-13 & INPA37665-JUF1 \\
\hline Hyphessobrycon epicharis & $\begin{array}{r}\text { São Gabriel d } \\
\text { Amaz }\end{array}$ & Negro & Brazil & НYР003-13 & INPA37665-JUF2 \\
\hline Hyphessobrycon megal & - & - & 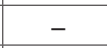 & 58 & - \\
\hline Hyphessobry & - & - & - & & - \\
\hline Hyphessobrycon pyrrhonotus & $\begin{array}{r}\text { Santa Isabel do r } \\
\text { Amazon }\end{array}$ & Negro & Brazil & $9-13$ & $\begin{array}{l}\text { INPA37672- } \\
\text { TRO1 }\end{array}$ \\
\hline Hyphessobrycon pyrrhonotus & $\begin{array}{r}\text { Santa Isabel do } \\
\text { Amazor }\end{array}$ & Negro & Brazil & НYР040-13 & $\begin{array}{l}\text { INPA37672- } \\
\text { TRO10 }\end{array}$ \\
\hline Hyphessobrycon pyrrhonotus & $\begin{array}{r}\text { Santa Isabel do } \\
\text { Amazo }\end{array}$ & Negro & Brazil & НYР042-13 & $\begin{array}{l}\text { INPA37672- } \\
\text { TRO2 }\end{array}$ \\
\hline Hyphessobrycon socolofi & $\begin{array}{r}\text { Santa Isabel d } \\
\text { Amaz }\end{array}$ & Negro & Brazil & НYР020-13 & INPA37667-UR1 \\
\hline Hyphessobrycon socolofi & $\begin{array}{c}\text { Santa Isabel do rio Negro, } \\
\text { Amazonas }\end{array}$ & Negro & Brazil & HYP022-13 & INPA37667-UR7 \\
\hline Hyphessobry & $\begin{array}{r}\text { São Gabriel da } \\
\text { Amazor }\end{array}$ & Negro & Brazil & HYP032-13 & $\begin{array}{l}\text { INPA37669- } \\
\text { MAC4 }\end{array}$ \\
\hline Hyphessobrycon rosaceus & Nova Airão, & Negro & Brazil & НYР069-13 & NPA37677-FU1 \\
\hline Hyphessobrycon rosaceus & $\begin{array}{c}\text { São Gabriel da Cachoeira, } \\
\text { Amazonas }\end{array}$ & Negro & Brazil & HYP082-13 & INPA37682-ACA1 \\
\hline Hyphessobrycon sweglesi & $\begin{array}{c}\text { São Gabriel da Cachoeira, } \\
\text { Amazonas }\end{array}$ & Negro & Brazil & НYР024-13 & INPA37668-JAR1 \\
\hline Hyphessobrycon sweglesi & $\begin{array}{c}\text { São Gabriel da Cachoeira, } \\
\text { Amazonas }\end{array}$ & Negro & Brazil & HYP025-13 & INPA37668-JAR2 \\
\hline Hyphessobrycon sweglesi & $\begin{array}{c}\text { São Gabriel da Cachoeira, } \\
\text { Amazonas }\end{array}$ & Negro & Brazil & HYP028-13 & INPA37668-JAR5 \\
\hline $\begin{array}{l}\text { Moenkhausia } \\
\text { hemigrammoides }\end{array}$ & Rupununi Road-Guyana & - & Guyana & HYP101-13 & INPA38532-PR1 \\
\hline
\end{tabular}




\begin{tabular}{l|c|c|c|c|c}
\hline \multicolumn{1}{c|}{ Species } & Locality & $\begin{array}{c}\text { Basin/ } \\
\text { drainage }\end{array}$ & Country & $\begin{array}{c}\text { GenBank/ } \\
\text { BoldSystems }\end{array}$ & Catalog number \\
\hline Pristella maxillaris & - & - & - & KU568982.1 & - \\
\hline Pristella maxillaris & - & - & - & KU568981.1 & - \\
\hline Hyphessobrycon flammeus & - & - & Brazil & FUPR988-09 & LBPV-40464 \\
\hline Hyphessobrycon anisitsi & - & - & Brazil & GBGCA516-10 & FJ749040 \\
\hline
\end{tabular}

species are treated as hypothetical and could be tested by the application of distinct criteria (species delimitation methods) (de Queiroz 2005, 2007). It allows for any criteria to separately provide evidence about species limits and identities, independently from other criteria (de Queiroz 2005, 2007). Evidence corroborated from multiple operational criteria is considered to produce stronger hypotheses of lineage separation (de Queiroz 2007, Goldstein and Desalle 2010), a practice called "integrative taxonomy" (Dayrat 2005, Goldstein and Desalle 2010, Padial et al. 2010).

Two distinct operational criteria to delimit species, based on morphological and molecular data, were implemented here. The Population Aggregation Analysis (Davis and Nixon 1992) is a character-based method (hereafter PPA), which consists of an exclusive shared combination of character states assigned to a given population or group of populations. The second method, DNA barcoding, as proposed by Hebert et al. (2003 a, b, 2004 a, b) (hereafter DBC), is a genetic distance-based cut-off method.

\section{Population Aggregation Analysis (PAA)}

Only morphological character states were used for this method. The morphological data was based on both examined material (see Comparative material examined) and the literature (e.g., Géry 1977, Géry and Uj 1987, Costa and Géry 1994, Plaquete et al. 1996, Weitzman and Palmer 1997, Zarske 2008, Hein 2009, Carvalho 2011, Lima et al. 2013, Zarske 2014, Carvalho and Malabarba 2015, Carvalho et al. 2017). The data obtained by this method are presented in the diagnosis section of results.

\section{DNA barcoding (DBC)}

Pairwise genetic distances between species were calculated using Kimura-2-parameters model (K2P) (Kimura 1980) on the MEGA 7 software (Tamura et al. 2011). Evolutionary relationships among sequences were reconstructed by Bayesian inference using the MrBayes (Huelsenbeck and Ronquist 2001) plugin in Geneious 9.0.5. An independent run with a chain length of 10 million, a burn-in length of 500,000 generations, and subsampling trees every 10,000 generations was carried out under the GTR (generalized time reversible) evolutionary model, which was estimated in jmodeltest (Darriba et al. 2012). Hyphessobrycon flammeus Myers, 1924 and H. anisitsi (Eigenmann, 1907) were used as outgroup. The ingroup was composed by the remaining terminals. 


\section{Results}

\section{Hyphessobrycon piorskii sp. n.} http://zoobank.org/379CFBEA-C3FE-4729-9469-029732DC62BC Figures 1, 2

Holotype. CICCAA 00695, 25.9 mm SL, Brazil, Maranhão State: stream at the An-

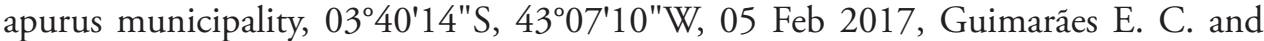
Brito P. S.

Paratypes. All from Brazil, Maranhão State: CICCAA 00430, 15,18.4-25.2 mm SL; CICCAA 00696, 15, 19.9-24.4mm SL, CICCAA 00697, 16 (C\&S) 19.3-24.5 mm SL; CICCAA 00698, 6, 1 (C\&S) 22.0-20.4 mm SL; CICCAA 00750, 9, 20.0-25.3mm SL; CPUFMA 171664, 15, 19.5-23.1 mm SL; UFRJ 11553, 6, 19.1-22.1 mm SL collected with holotype. CICCAA 00089, 1 (C\&S) $25.2 \mathrm{~mm}$ SL, stream at Mata de Itamacaoca, Chapadinha municipality; $03^{\circ} 44^{\prime} 50^{\prime \prime S}, 43^{\circ} 19^{\prime} 21^{\prime \prime W}, 02$ Apr. 2016, Ottoni F. P., Oliveira E., Nascimento I., Fernandes R., Carneiro V. leg. CICCAA 00431, 21, 15.3-19.8mm

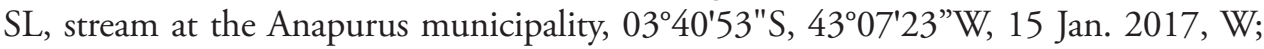
Aguiar R. leg. CICCAA 00881, 1, $29.4 \mathrm{~mm}$ SL, stream at Mata de Itamacaoca, Chapadinha municipality; 034ㄴ $45^{\prime}$ "S, $45^{\circ} 19^{\prime} 15^{\prime}$ W, 15 Jul. 2017, Campos D., Oliveira E., Viana S., Lopes M., Sousa R. leg. CICCAA 01563, 1, $21.6 \mathrm{~mm}$ SL, stream at Mata de Itamacaoca, Chapadinha municipality; 03⒋'55"S 4319'55"W, 19 Nov. 2017, Guimarães E. C., Brito P. S., Ottoni F. P., Lucas O., Sousa R. leg. CICCAA01654, 1, 26.9 mm SL, stream at the Anapurus municipality, 03\% $40^{\prime} 14^{\prime \prime S}, 43^{\circ} 07^{\prime} 10^{\prime \prime W}, 17$ Jan. 2018, Guimarães E. C. and Brito P. S. leg. CICCAA 01382, 5, 22.7-27.2 mm SL, stream at Mata Fome, Barreirinhas municipality, 02³9'47"S, 42\%48'16"W, 15 Jun., 2017, Guimarães E. C., Brito P. S., Ottoni F. P., Ferreira B. R. CICCAA 02008, 12 (C\&S), 15.4-18.3 mm SL, stream at Mata Fome, Barreirinhas municipality; 02 $39^{\prime} 47^{\prime \prime} S, 42^{\circ} 48^{\prime} 16^{\prime W}, 15$ Jun., 2017, Guimarães E. C., Brito P. S., Ottoni F. P., Ferreira B. R. leg.

Diagnosis (PAA). The new species Hyphessobrycon piorskii sp. n., promptly differs from most congeners except by species of Hyphessobrycon sensu stricto by the presence of a dark brown or black blotch on dorsal fin (vs. absence), no midlateral stripe on the body (vs. presence) and Weberian apparatus upward horizontal through dorsal margin of operculum (vs. downward).

The new species herein described differs from all of its congeners from Hyphessobrycon sensu stricto, with exception to $H$. bentosi and $H$. hasemani, by possessing an inconspicuous vertically elongated humeral spot [vs. approximately rounded humeral spot in $H$. copelandi, H. erythrostigma, H. jackrobertsi, H. minor, H. pando, H. paepkei, $H$. pyrrhonotus, $H$. roseus, $H$. socolofi, and $H$. sweglesi; humeral spot horizontally or posteriorly elongated in $H$. epicharis, $H$. khardinae, and $H$. werneri; conspicuous humeral spot in $H$. eques, $H$. haraldschultzi Travassos, 1960, H. micropterus, H. megalopterus, $H$. simulatus and $H$. takasei; and absence of humeral spot in $H$. compresus, $H$. dorsalis Zarske, 2014, H. georgettae, $H$. pulchripinnis, and $H$. rosaceus]. 


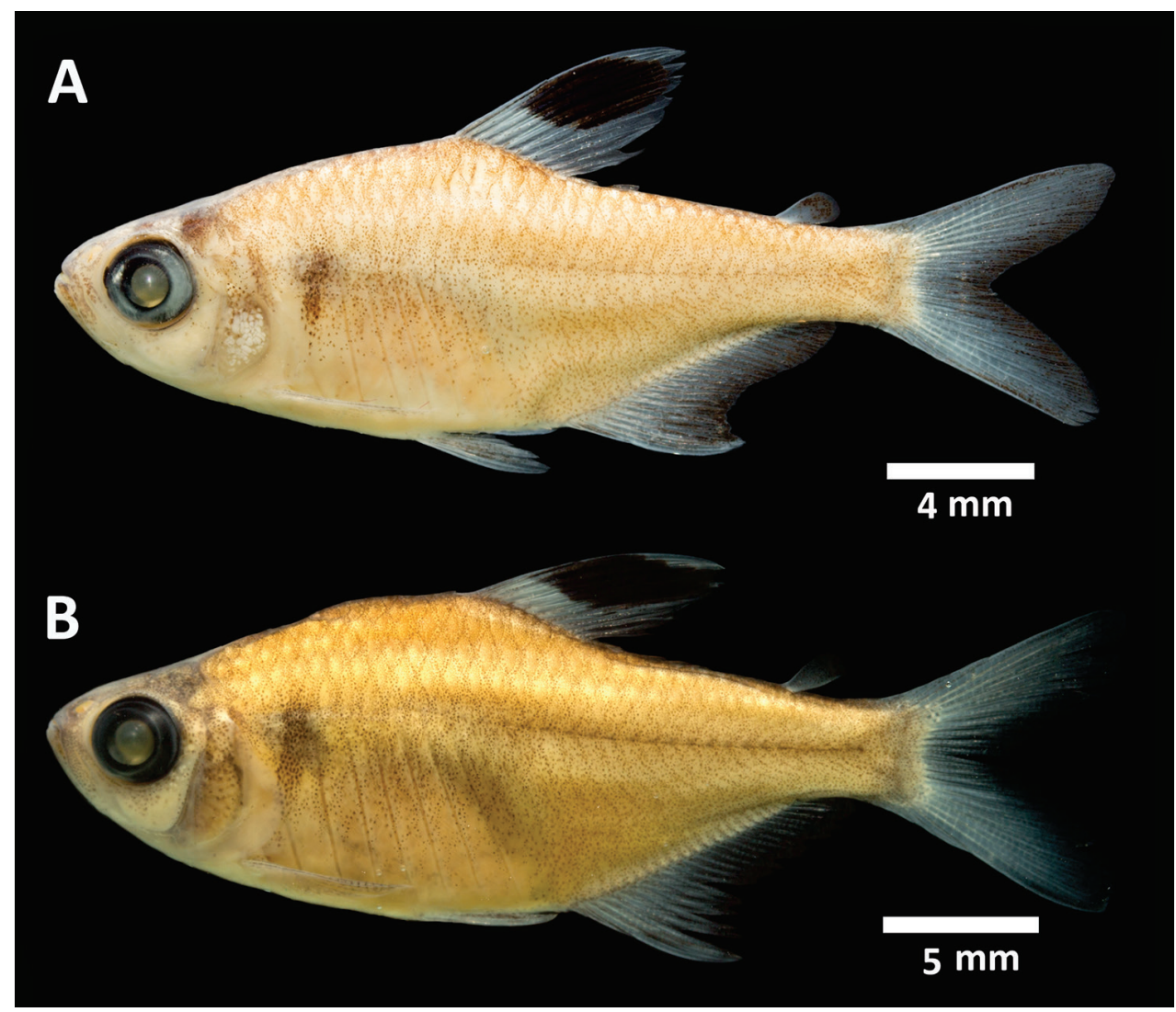

Figure I. Hyphessobrycon piorskii sp. n. A CICCAA 00695, holotype, 25.9 mm SL, Brazil: Maranhão State: Munim River basin B CICCAA 00881, paratype, 29.4 mm SL, Brazil: Maranhão State: Munim River basin (photographed by Felipe Ottoni).

The new species differs from $H$. bentosi by the absence of an extended and pointed dorsal and anal-fin tips (Figures 1, 2) [vs. extended and pointed dorsal and anal-fin tips]; and from $H$. hasemani by the dorsal-fin black spot shape, which is located approximately at the middle of the fin's depth, not reaching its tip [vs. extended along all the fin, reaching its tip in adults] and by presenting tri to unicuspid teeth in the inner row of premaxillary and dentary [vs. pentacuspid teeth].

Description. Morphometric data of holotype and paratypes are presented in Table 3. Body compressed, moderately deep, greatest body depth slightly anterior to dorsal-fin base. Body profile straight and downward directed from end of dorsal fin to adipose fin, straight or slightly convex between later point and origin of dorsal most procurrent caudal-fin ray. Dorsal profile of head convex from upper lip to vertical through eye; predorsal profile of body roughly straight, dorsal-fin base slightly convex, posteroventrally inclined; ventral profile of head convex from lower jaw to pelvic-fin 


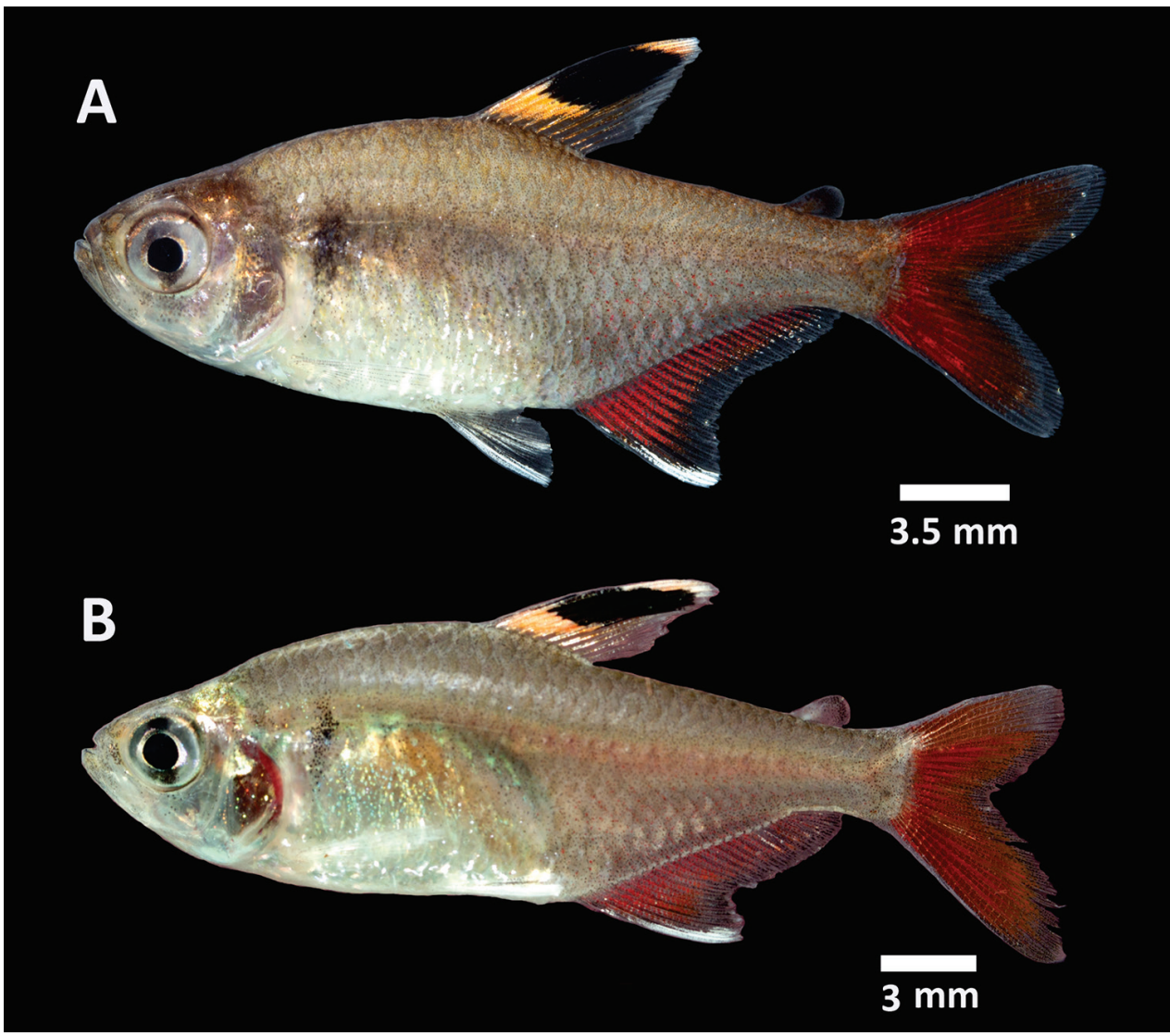

Figure 2. Hyphessobrycon piorskii sp. n. A CICCAA 00698, paratype, 26.9 mm SL, Brazil: Maranhão State: Munim River basin; living specimen photographed immediately after collection B CICCAA 00089, paratype, $25.2 \mathrm{~mm}$ SL, Brazil: Maranhão State: Munim River basin; living specimen photographed immediately after collection (photographed by Felipe Ottoni).

origin. Ventral profile of body straight or slightly convex from pelvic-fin origin to anal-fin origin; straight and posterodorsally slanted along anal-fin base; and slightly concave on caudal peduncle. Jaws equal, mouth terminal, anteroventral end of dentary protruding. Maxilla reaching vertical to anterior margin of pupil. Premaxillary teeth in two rows. Outer row with one tricuspid tooth; inner row with 6(6), 7(20) or 8(4) tricuspid teeth and one unicuspid tooth. Maxilla with 3(5), 5(24) or 6(1) tricuspid teeth. Dentary with five (21) or six (9) larger tricuspid teeth followed by one smaller tricuspid teeth 5(2), 6(6), 7(13), 8(5), 9(4) smaller unicuspid teeth (Figure 3). Scales cycloid, three to eight radii strongly marked, circuli well-marked anteriorly, weakly-marked posteriorly; lateral line incompletely pored, with 6(19), 7(62) or 8(13) perforated scales. Longitudinal scales series including lateral-line scales 31(9), 32(34), 33(26), 34(17) or 35(3). Longitudinal scales rows between dorsal-fin origin and lateral line 6(49) or 7(41). Horizontal scale 


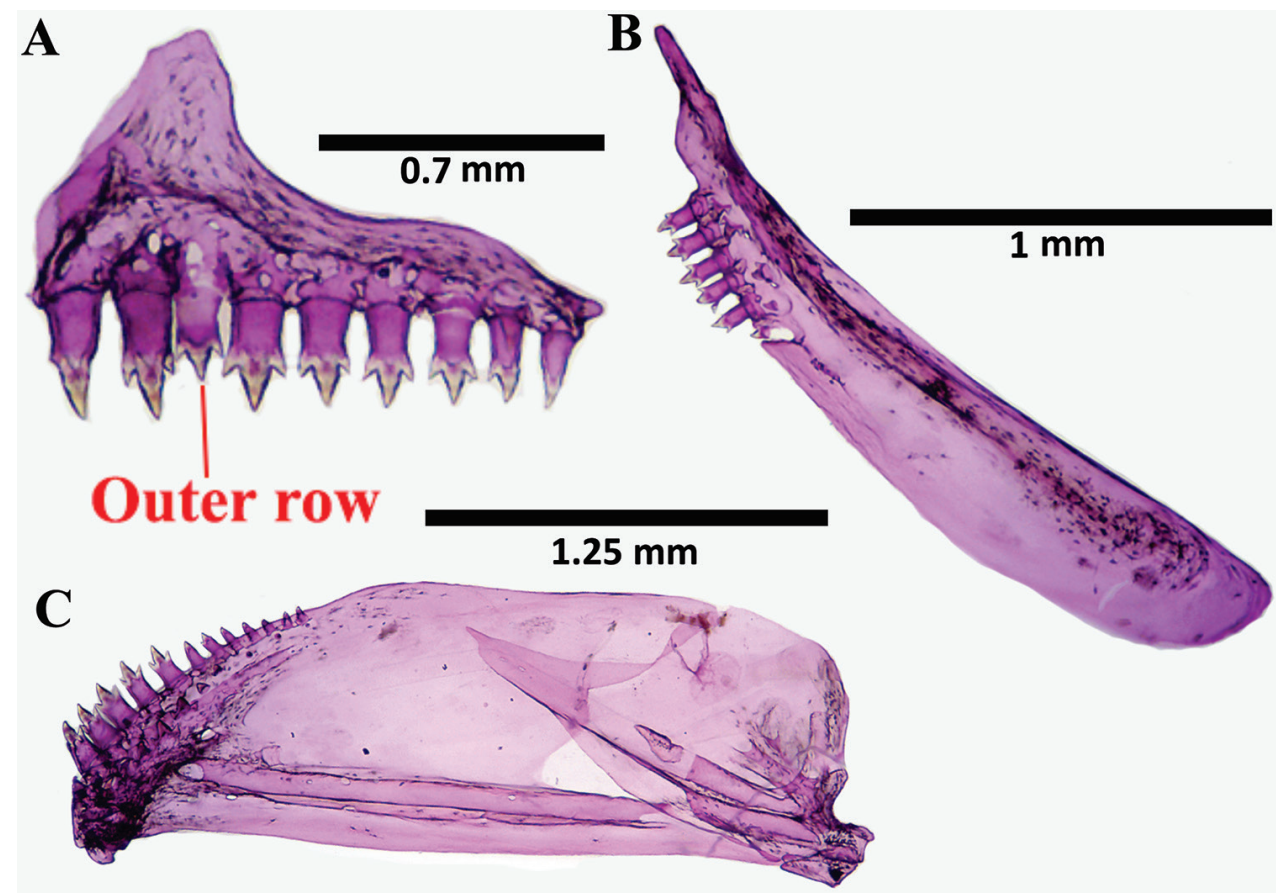

Figure 3. Hyphessobrycon piorskii sp. n. CICCAA 00697, 19.3 mm SL; jaw suspensory: A Premaxillary. B Maxilla C Dentary (Photographed by Erick Guimarães).

rows between lateral line and pelvic-fin origin $4(18)$ or $5(71)$. Scales in median series between tip of supraoccipital spine and dorsal-fin origin 8(6), 9(14), 10(7) or 11(3). Circumpeduncular scales 11(16), 12(38) or 13(11). Dorsal-fin rays i $+10(105)$ or ii $+10(18)$. First dorsal-fin pterygiophore main body located behind neural spine of $4^{\text {th }}$ vertebrae. Adipose fin present. Anteriormost anal-fin pterygiophore inserting posterior to haemal spine of $11^{\text {th }}$ vertebrae. Anal-fin ii+24(3), iii+24(87), ii-25(32) or iii+25(1). Anterior anal-fin margin slightly convex, with anteriormost rays more elongate and slightly more thickened than remaining rays, forming a distinct lobe. Remaining rays smaller with straight distal margin. Anal-fin rays with a sexually dimorphic pattern, which are absent in females (Figure 4). Pectoral fin-rays 12(122) or 13(1) total rays. Tip of pectoral fin usually reaching vertical through pelvic-fin origin. Pelvic-fin rays 8(125) total rays. Pelvic-fin rays with a sexually dimorphic pattern, which are absent in females (Fig. 5). Caudal fin forked, upper and lower lobes similar in size. Principal caudal-fin rays $10+9(121), 10+10(7)$ or $11+10(17)$; dorsal procurrent rays $7(1), 9(13), 10(13)$ or $11(3)$ and ventral procurrent rays 6(1), 7(8), 8(12) or 9(9). Branchiostegal rays 4(30). First gill arch with 1(1), 2(29) hypobranchial, 11(1), 12(28) or 13(1) ceratobranchial, 1(30) on cartilage between ceratobranchial and epibranchial, and 5(1) or 6(16) epibranchial gill-rakers. Supraneurals 3(2) 4(23) or 5(5). Total vertebrae 29(30). 
Color in alcohol Figure 1. Ground coloration light yellowish brown. Humeral region with one inconspicuous vertically elongated spot; more intensely pigmented on its central portion. Flank with chromatophores homogeneously scattered, more concentrated on posterior region to humeral spot, posterior region of dorsal-fin base origin and below mid-portion of trunk, between anal-fin origin and caudal peduncle. Ventral region lacking dark brown chromatophores. Dark brown chromatophores present on head and more concentrated on dorsal portion, becoming sparser on cheek and preopercular regions.

Dorsal fin ground coloration hyaline, with a conspicuous black or dark brown spot located on anterior portion of fin, reaching about sixth ray, approximately between half to two thirds of fin depth. Anal and caudal fins hyaline. Caudal fin with a darker, usually dark brown, posterior margin and on its base. Adipose fin hyaline to light brown, with dark brown or black chromatophores more concentrated on its dorsal portion, depending on the state of preservation of the specimen. Pectoral and pelvic fins hyaline; pelvic fin with variable amounts dark brown pigmentation remaining depending on the state of preservation of the specimen.

Color in life (Figure 2). Pattern similar to coloration of preserved specimens. Ground coloration light yellowish brown to grey, with a reddish-brown pigmentation on vertebrae region, and usually with red chromatophores. Ventral region anterior to anal-fin origin lighter. Humeral spot inconspicuously dark brown or black. Head with same coloration as body, and ventrally lighter.

Conspicuous black spot on dorsal-fin, with yellow or orange pigmentation on dorsal and ventral margins of spot; yellow or orange pigmentation lighter and less evident on dorsal margin, reaching half to two thirds of the spot length and extending to the tip of fin; yellow or orange pigmentation darker and more developed at ventral margin of the spot, reaching entire spot base length, not extended to dorsal fin-base. Rest of dorsal fin hyaline. Anal-fin base with red pigmentation, with different degrees of intensity, with milk white pigmentation on anterior tip of anal fin, which could be extended through entire anterior margin, reaching between second to fourth rays. Posterior margin of anal fin with an inconspicuous dark brown pigmentation. Adipose fin light brown to hyaline at base, with red to black pigmentation at tip. Pectoral and pelvic fins hyaline, with some sparser dark brown chromatophores, more concentrated at pelvic fin base. First ray of pelvic fin with a white pigmentation. Caudal fin with red pigmentation on almost fin, with an inconspicuous light brown, reddish brown or dark brown margin.

Sexual dimorphism. Mature males have hooks on anal-fin and pelvic-fin rays. Hooks absent on females. Anal-fin presenting hooks from $3^{\text {rd }}, 4^{\text {th }}$ or $5^{\text {th }}$ rays through last ray. Number of hooks variable, increasing from the first ones to the last rays. Pelvic fin presenting $3^{\text {rd }}$ and $4^{\text {th }}$ rays with 5 smaller hooks (Figures 4,5 ).

DNA-based identification. After trimming sequence ends with poor base call quality, the final alignment yielded 446 base pairs with 154 variable sites, and 22 haplotypes. The magnitude of sequence divergence clearly demonstrates the exist- 


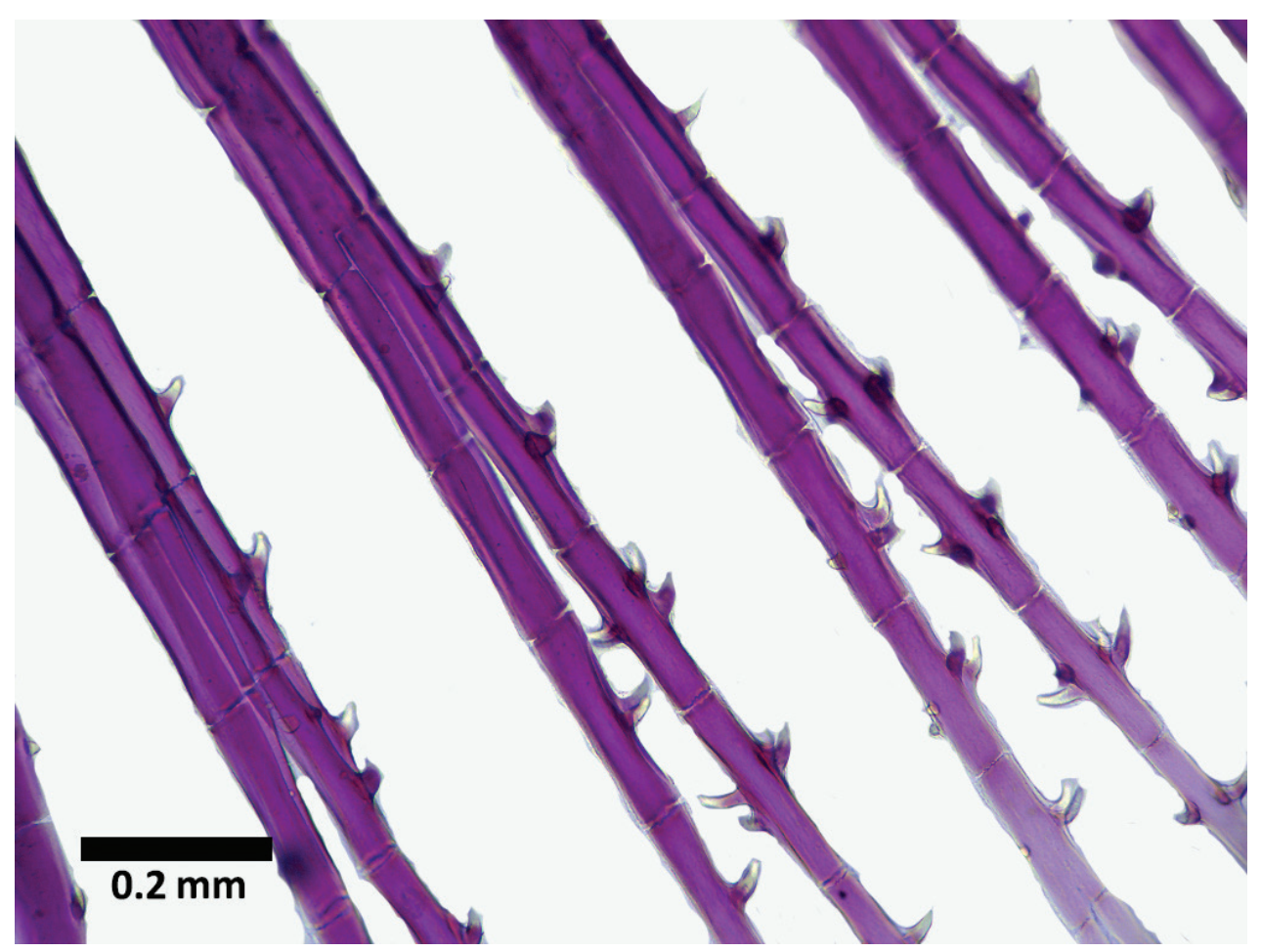

Figure 4. Hyphessobrycon piorskii sp. n. CICCAA 00697, male, $19.3 \mathrm{~mm}$ SL, bony hooks on anal fin (photographed by Erick Guimarães).

ence of a new species of Hyphessobrycon inhabiting the Munim and Preguiças river basins in Maranhão State. Average genetic distances were 14.2\%, with the highest values between $H$. pyrrhonotus and $H$. epicharis (19.2\%), while the lowest value (2.7\%) was between $H$. epicharis and $H$. sweglesi (Table 1). Hyphessobrycon piorskii sp. n. has $17 \%$ sequence divergent, on average, from the other taxa, with a minimum distance with $H$. eques $(13.9 \%)$ and a maximum with $H$. rosaceus $(18.4 \%)$ (Table 2).

Other evidence for the new species is that $H$. piorskii sp. n. formed a single and exclusive clade with maximum posterior probability support (posterior probability = 1) in the Bayesian phylogenetic tree (Figure 7). Furthermore, H. piorskii sp. n. clade is located within the Hyphessobrycon s. str. group with high support of posterior probability (0.94). Hyphessobrycon piorskii sp. n. was recovered as the sister-group of the clade including $H$. bentosi, $H$. socolofi, $H$. megalopterus, $H$. erythrostigma and $H$. pyrrhonotus, with branch support of posterior probability value of 0.55 . Pristella maxillaris and Moenkhausia hemigrammoides formed a clade (posterior probability value $=0.86$ ), and it was recovered as the sister-clade of the Hyphessobrycon s. str. group (posterior probability value $=0.6$ ). 


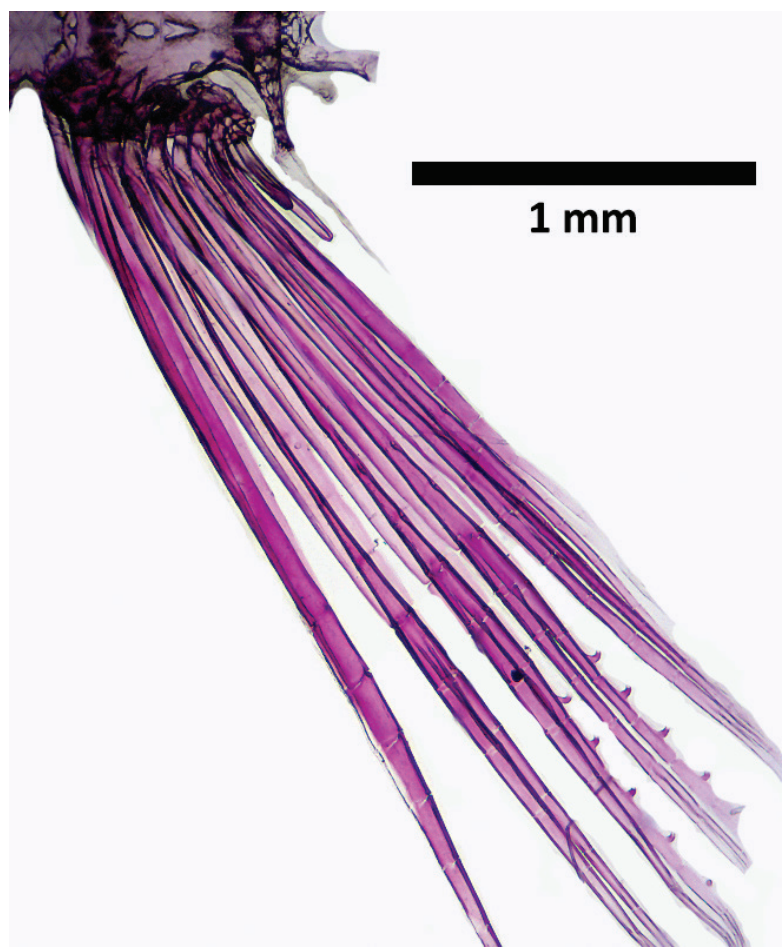

Figure 5. Hyphessobrycon piorskii sp. n. CICCAA 00697, male, $19.3 \mathrm{~mm} \mathrm{SL}$, bony hooks on pelvic fin (photographed by Erick Guimarães).

Geographical distribution. Hyphessobrycon piorskii sp. n. is presently known only from the upper Munim and Preguiças river basins, Maranháo State, northeastern Brazil (Figure 7).

Ecological notes. Hyphessobrycon piorskii sp.n. lives in shallow well-oxygenated streams with transparent waters flowing over different types of substrates (Figure 8). The streams where $H$. piorskii sp. n. specimens were collected varied from 0.90 to 10 meters wide, with a maximum depth of 1.60 meters. They possessed moderate water currents $(0.1-0.7 \mathrm{~m} / \mathrm{s})$, with clear, sandy substrates with pebbles, mud, leaf litter, and submerged logs, often also presenting aquatic macrophytes. Hyphessobrycon piorskii sp. n. was found near shore among aquatic vegetation, tree roots and fallen logs. Other species found at both sites were Anablepsoides vieirai Nielsen, 2016, Apistogramma piauiensis Kullander, 1980, Astyanax sp., Cichlasoma cf. zarkei, Copella arnoldi (Regan, 1912), Crenicichla brasiliensis (Bloch, 1792), Hoplias malabaricus (Bloch, 1794), Megalechis thoracata (Valenciennes, 1840), Nannostomus beckfordi Günther, 1872, and Synbranchus marmoratus Bloch, 1795. Gut contents of C\&S specimens contained algae and disarticulated arthropod remains.

Etymology. The name piorskii honors the ichthyologist Nivaldo Magalhães Piorski for his contributions to the ichthyologic knowledge of the Maranhão State. 
Table 2. Kimura-2 parameters pairwise genetic distances among species. Species names in the upper columns are abbreviated as follows: H. piorskii (Hpio), H. flammeus (Hfla), H. anisitsi (Han), H. socolofi (Hsoc), H. copelandi (Hcop), H. bentosi (Hben), H. megalopterus (Hmeg), H. eques (Hequ), H. erythrostigma (Hery), H. pyrrhonotus(Hpyr), H. rosaceus (Hros), H. sweglesi (Hswe), H. epicharis (Hepi), M. hemigrammoides (Mhem), and P. maxillaris (Pmax).

\begin{tabular}{l|c|c|c|c|c|c|c|c|c|c|c|c|c|c}
\hline Species & Hpio & Hfla & Hani & Hsoc & Hcop & Hben & Hmeg & Hequ & Hery & Hpyr & Hros & Hswe & Hepi & Mhem \\
\hline Hfla & 0.190 & - & & & & & & & & & & & & \\
\hline Hani & 0.194 & 0.165 & - & & & & & & & & & & & \\
\hline Hsoc & 0.199 & 0.193 & 0.168 & - & & & & & & & & & & \\
\hline Hcop & 0.158 & 0.206 & 0.162 & 0.216 & - & & & & & & & & & \\
\hline Hben & 0.207 & 0.204 & 0.173 & 0.008 & 0.221 & - & & & & & & & & \\
\hline Hmeg & 0.195 & 0.209 & 0.180 & 0.087 & 0.213 & 0.086 & - & & & & & & & \\
\hline Hequ & 0.161 & 0.205 & 0.186 & 0.190 & 0.102 & 0.194 & 0.199 & - & & & & & & \\
\hline Hery & 0.196 & 0.213 & 0.182 & 0.114 & 0.191 & 0.117 & 0.131 & 0.174 & - & & & & & \\
\hline Hpyr & 0.183 & 0.206 & 0.166 & 0.101 & 0.191 & 0.103 & 0.117 & 0.181 & 0.032 & - & & & & \\
\hline Hros & 0.218 & 0.212 & 0.205 & 0.224 & 0.202 & 0.227 & 0.204 & 0.195 & 0.219 & 0.221 & - & & & \\
\hline Hswe & 0.205 & 0.187 & 0.195 & 0.224 & 0.198 & 0.229 & 0.192 & 0.183 & 0.216 & 0.211 & 0.073 & - & & \\
\hline Hepi & 0.199 & 0.190 & 0.198 & 0.221 & 0.198 & 0.226 & 0.199 & 0.183 & 0.233 & 0.231 & 0.089 & 0.028 & - & \\
\hline Mhem & 0.185 & 0.204 & 0.178 & 0.214 & 0.216 & 0.219 & 0.234 & 0.205 & 0.233 & 0.222 & 0.200 & 0.204 & 0.208 & - \\
\hline Pmax & 0.223 & 0.212 & 0.197 & 0.203 & 0.219 & 0.207 & 0.218 & 0.200 & 0.230 & 0.239 & 0.202 & 0.187 & 0.181 & 0.169 \\
\hline
\end{tabular}

Table 3. Morphometric data $(\mathrm{N}=95)$ for the holotype and paratypes of Hyphessobrycon piorskii sp. $\mathrm{n}$. from the Munim River basin and Preguiças River basin. Abbreviations: SD: Standard deviation.

\begin{tabular}{|c|c|c|c|c|}
\hline & Holotype & Paratypes & Mean & SD \\
\hline Standard length & 25.9 & $18-29.4$ & 20.8 & - \\
\hline \multicolumn{5}{|l|}{ Percentages of standard length } \\
\hline Depth at dorsal-fin origin (body depth) & 35.9 & $28.9-39.4$ & 33.4 & 1.9 \\
\hline Snout to dorsal-fin origin & 49.8 & $44.2-56.5$ & 52.5 & 2.1 \\
\hline Snout to pectoral-fin origin & 29.1 & $26.0-35.0$ & 30.8 & 2.3 \\
\hline Snout to pelvic-fin origin & 47.5 & $39.1-52.2$ & 47.5 & 1.9 \\
\hline Snout to anal-fin origin & 61.9 & $57.4-66.6$ & 61.7 & 1.8 \\
\hline Caudal peduncle depth & 11.8 & $9.1-14.1$ & 11.4 & 0.9 \\
\hline Caudal peduncle length & 12.2 & $8.1-13.6$ & 10.2 & 1.1 \\
\hline Pectoral-fin length & 20.4 & $16.8-23.7$ & 20.8 & 1.6 \\
\hline Pelvic-fin length & 18.1 & $13.3-20.4$ & 17.1 & 1.5 \\
\hline Dorsal-fin base length & 15.5 & $12.9-18.3$ & 15.7 & 1.2 \\
\hline Dorsal-fin height & 28.5 & $22.1-34.3$ & 29.9 & 2.4 \\
\hline Anal-fin base length & 29.4 & $26.3-33.9$ & 30.3 & 1.4 \\
\hline Eye to dorsal-fin origin & 35.2 & $33.6-39.4$ & 36.4 & 1.4 \\
\hline Dorsal-fin origin to caudal-fin base & 50.7 & $44.9-57.3$ & 51.4 & 2.3 \\
\hline Head length & 26.3 & $24.2-33.4$ & 29.3 & 2.1 \\
\hline \multicolumn{5}{|l|}{ Percentages of head length } \\
\hline Horizontal eye diameter & 42.8 & $33.4-43.8$ & 38.2 & 2.3 \\
\hline Snout length & 22.0 & $16.9-24.4$ & 20.2 & 1.7 \\
\hline Least interorbital width & 25.7 & $16,4-27.0$ & 20.4 & 2.2 \\
\hline Upper jaw length & 39.6 & $32.8-41.7$ & 38.1 & 2.2 \\
\hline
\end{tabular}




\section{Discussion}

Despite Hyphessobrycon, as defined today, being a non-monophyletic group (Mirande 2010, Oliveira et al. 2011, Carvalho et al. 2017, Ohara et al. 2017, Moreira and Lima 2017), a few putative groups within the genus were proposed in the literature. One such case is the Hyphessobrycon sensu stricto as defined by Carvalho (2011) and Cavalho and Malabarba (2015). According to those authors, this group is composed by approximately 25 species.

Among the species considered by Weitzman and Palmer (1997) as possibly related to the "rosy tetra clade", only $H$. hasemani and $H$. pulchripinnis were considered to belong to Hyphessobrycon sensu stricto (Carvalho 2011, Carvalho and Malabarba 2015). Pristella maxillaris (Ulrey, 1894) is the sister-group of the Hyphessobrycon sensu stricto (Carvalho 2011), and corroborated in our analysis (Figure 6).

Hyphessobrycon piorskii sp. n. exhibits all the diagnostic features that define Hyphessobrycon sensu stricto (see introduction and diagnosis section). The new species differs from the other possible species of this assemblage, which also occur near Maranhão (e.g., lower Amazon River basin, Guamá River basin, and São Francisco River basin), such as $H$. bentosi, $H$. copelandi, $H$. eques, $H$. dorsalis, $H$. hasemani, $H$. haraldschultzi, $H$. micropterus, and H. werneri, by a set of features listed below.

Hyphessobrycon piorskii sp. n. possesses an inconspicuous vertically elongated humeral spot, distinguishing it from all the species cited above, except for $H$. bentosi and $H$. hasemani (see morphological diagnosis section). The shape of the dorsal-fin spot is also useful to distinguish $H$. piorskii sp. n. from $H$. eques, $H$. hasemani and $H$. micropterus, which possess dorsal fin spot vertically extended, reaching the tip of the fin, while in $H$. piorskii sp. n. the black spot of dorsal fin never reaches the tip of the fin. The new species also differs from $H$. eques by the color pattern of the anal fin: $H$. eques possess a conspicuous black anal-fin margin on preserved species, while $H$. piorskii sp. n. does not exhibit this feature at the anal fin.

The number of teeth cusps was also revealed to be a useful feature for species discrimination. Hyphessobrycon piorskii sp. n. possess all of its teeth with one to three cusps (never pentacuspid), while $H$. eques possess pentacuspid teeth on the maxillary and inner row of premaxillary, and $H$. copelandi and $H$. hasemani on the dentary and inner row of the premaxilla (see Lima et al. 2013). The new species differs from $H$. bentosi by not having extended and pointed dorsal and anal-fin tips and by having bone hooks on anal-fin rays of mature males (Figure 3). The dorsal and anal fins of $H$. bentosi have pointed and extended tips, and it has not bony hooks on anal-fin rays (see Carvalho 2011, Zarske 2014). Hyphessobrycon copelandi possesses only ten teeth on the dentary, and dorsal-fin black spot reaching to the posterior margin of the fin (see Lima et al. 2013), while $H$. piorskii sp. n. possesses 11-15 teeth on dentary, and dorsal-fin black spot restricted to the anterior half of the fin's length. In addition, Hyphessobrycon piorskii sp. $\mathrm{n}$. is easily distinguished from the sister-species of the clade Hyphessobrycon sensu stricto, P. maxillaris and $M$. hemigrammoides, by the absence of a black oblique stripe or band on the anterior portion of the anal fin (Figures 1, 2) [vs. presence (Carvalho et al. 2017, figure 7; pers. obs.)]. 


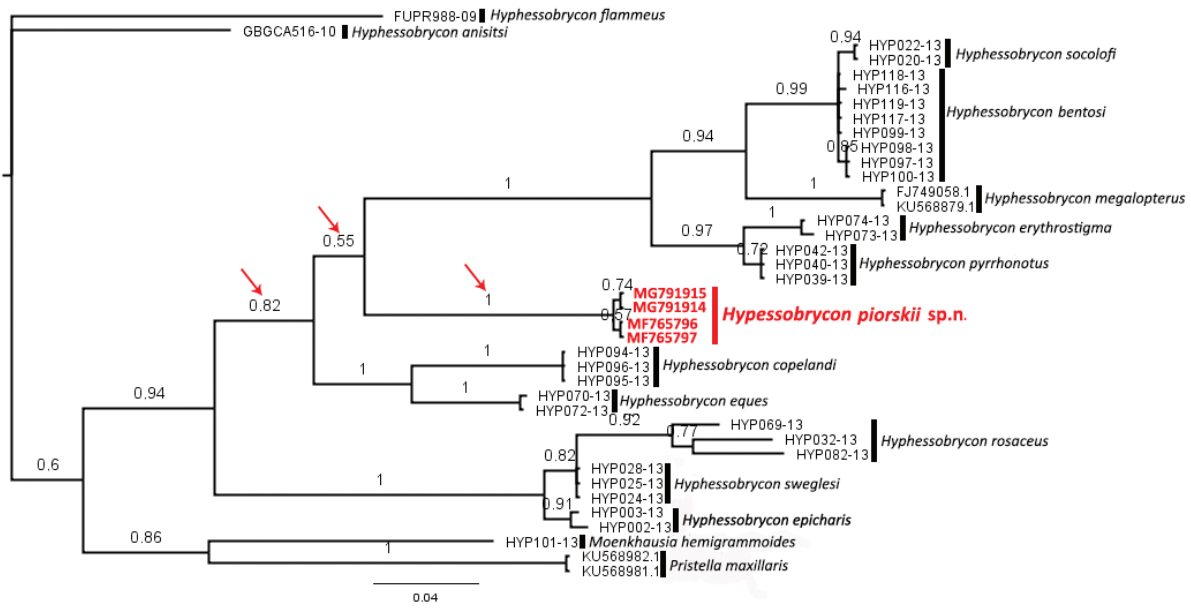

Figure 6. Bayesian phylogenetic tree including Hyphessobrycon piorskii sp. $\mathrm{n}$ (in red) and other congeners. Number above branches are posterior probability values.

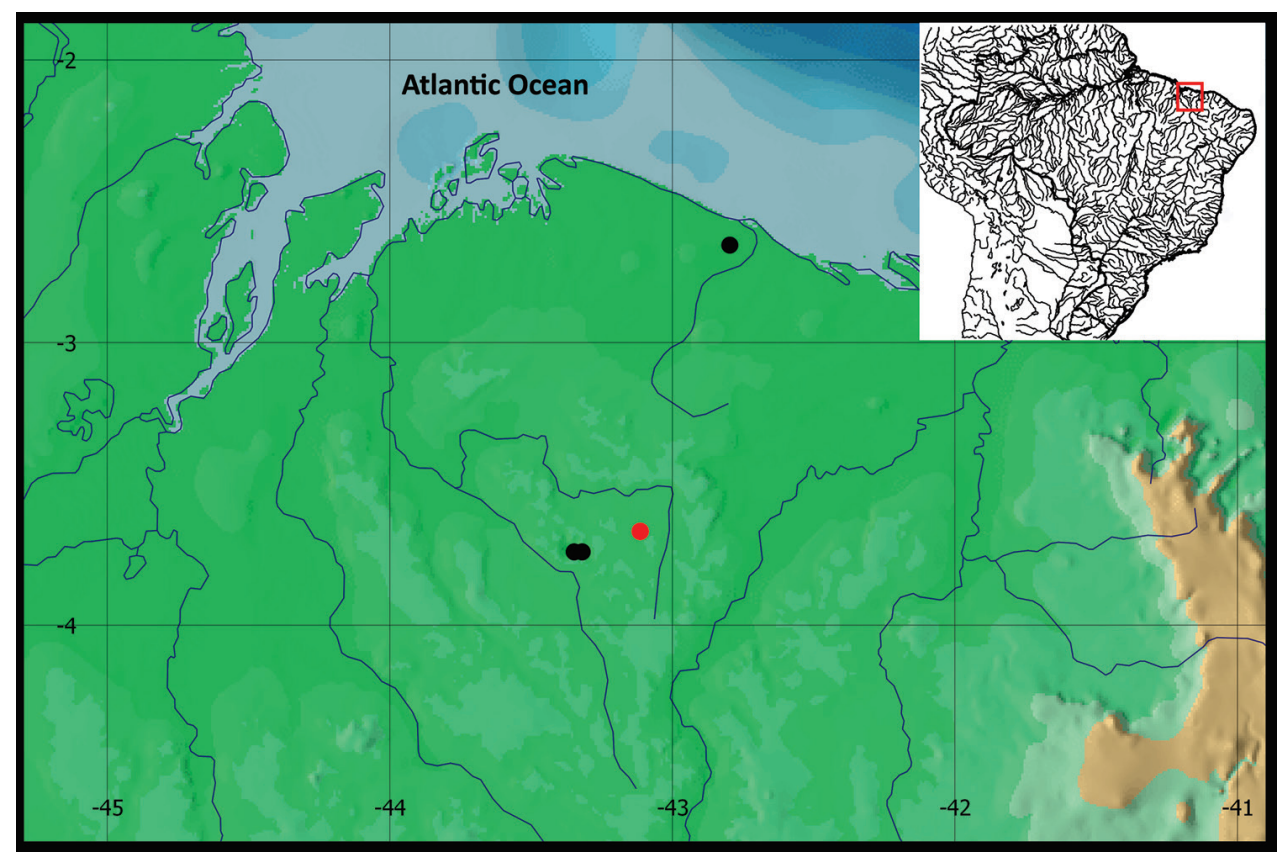

Figure 7. Geographical distribution of Hyphessobrycon piorskii sp. n. Red circle denote Holotype and black circle denote paratypes.

The description of $H$. piorskii sp. n. was based on morphological and molecular species delimitation methods, using the congruence of multiple operational criteria for determining species boundaries. As mentioned earlier, evidence corroborated from 


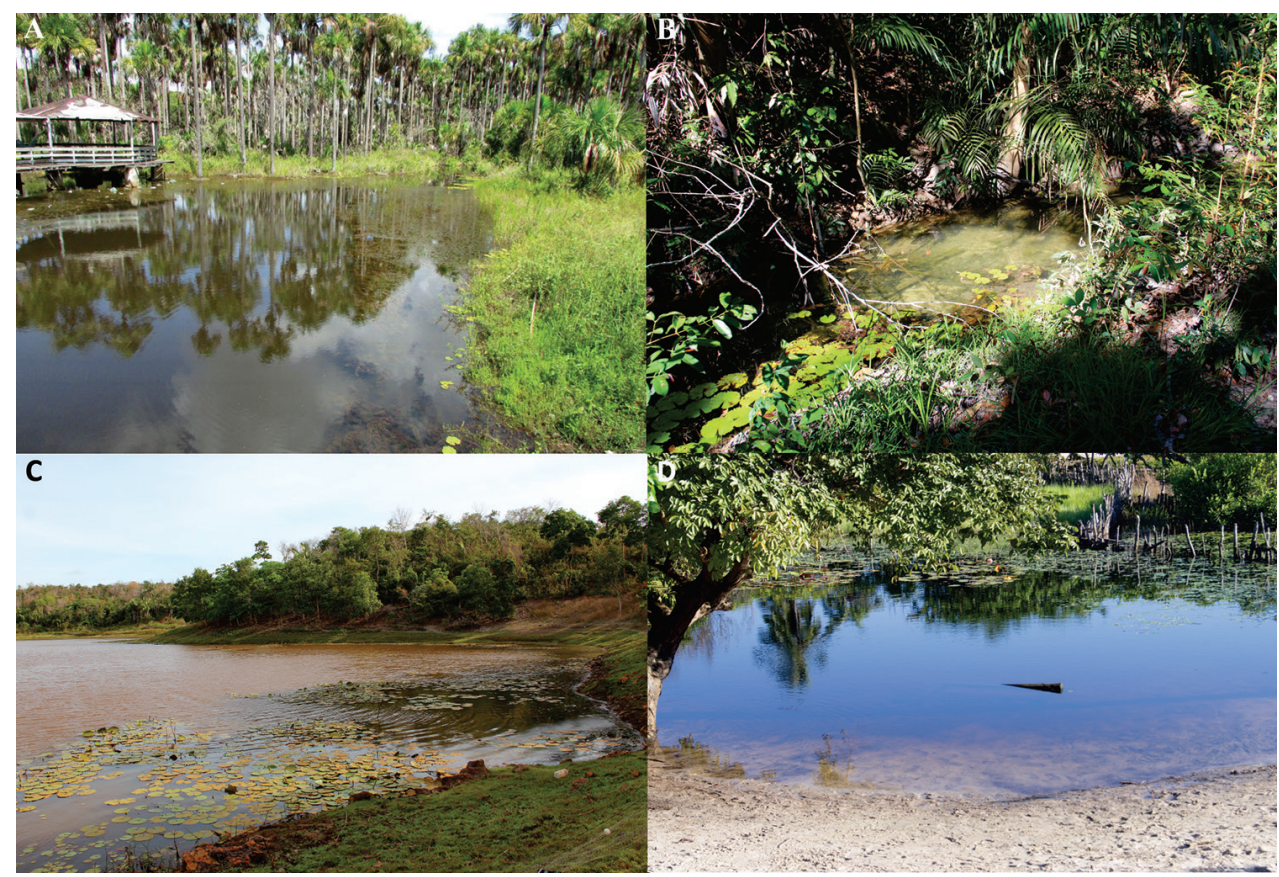

Figure 8. Collecting sites of Hyphessobrycon piorskii sp. n. A stream at the Anapurus municipality B stream at Mata de Itamacaoca $\mathbf{C}$ stream at Mata de Itamacaoca D stream at Mata Fome, Barreirinhas municipality (photographed by Felipe Ottoni).

multiple operational criteria is considered to produce stronger hypotheses of lineage divergence (de Queiroz 2007, Goldstein and Desalle 2010), thus congruent to the proposal for an integrative taxonomy (Goldstein and Desalle 2010, Padial et al. 2010). The morphological criteria (PAA) distinguished the new species from all of the other congeners by unambiguous character states (see diagnosis). The DNA barcoding (DBC) criteria also revealed that $H$. piorskii sp. n. is a new species with an average sequence divergence of $17 \%$ from the other taxa (Table 2). In addition, $H$. piorskii sp. n. is placed in an exclusive and highly supported clade in the Bayesian tree (Figure 6). Haplotypes clustered as an exclusive and high supported group, with geographical concordance area is evidence of lineage divergence, therefore a good and strong evidence for delimit species, and consequently describe them (Wiens and Penkrot 2002, Costa et al. 2014).

Our Bayesian tree also recovered $H$. piorskii sp. n. within the Hyphessobrycon sensu stricto group with high support (posterior probability $=0.94$ ), which fits the morphological evidence, since $H$. piorskii sp. n. exhibits the three main diagnostic character states of the group (see introduction and diagnosis section). Hyphessobrycon piorskii sp. n. was recovered as the sister-group of the clade including $H$. bentosi, $H$. socolofi, $H$. megalopterus, $H$. erythrostigma, and $H$. pyrrhonotus, however this relationship was supported by a lower support value (posterior probability value $=0.55$ ). Only posterior probability values about or higher than 0.95 are considered as statistically significant 
(Alfaro and Holder 2006). Therefore, any discussion about the relationship and supposed shared morphological features between $H$. piorskii sp. n. and this clade is speculative (Figure 7). To a better understanding of the internal relationships of the group, an analysis including more genes, especially from nuclear genome, is highly recommended. However, this was not the scope of the present paper. Pristella maxillaris and Moenkhausia hemigrammoides were recovered as the sister-clade of the Hyphessobrycon sensu stricto group, corroborating partially the results of Carvalho et al. (2011) and Carvalho and Malabarba (2015), who argue that $P$. maxillaris is the sister-clade of the Hyphessobrycon sensu stricto group.

\section{Acknowledgements}

We thank Wilson Costa for the loan and donation of material; Riccardo Mugnai for his assistance with osteological photographs; Ingo Schindler for providing useful literature; Vale S.A and Amplo Engenharia for the cession of part of the data analysed in this study; We also thank Pensoft and Clarisse Figueiredo for her English revisions; Elioenai Oliveira, Ivanilda Nascimento, Rozijane Fernandes, Valquíria Carneiro, Shyrley Viana, Marciara Lopes, Revangivaldo Sousa, Diego Campos, Pedro Bragança, Beldo Ferreira and Lucas Oliveira for collecting the examined material. This paper benefited from suggestions provided by Javier Maldonado and two reviewers: Jorge Enrique García Melo and Carlos García-Alzate. This study was supported by CNPq (National Council for Scientific and Technological Development - Ministry of Science, Technology Innovation and Communication) and FAPEMA (Foundation for Scientific Research and Development of Maranhão). We also thank FACEPE (Fundação de Amparo à Ciência e Tecnologia do Estado de Pernambuco) for providing a scholarship to LMF. All material was collected with permits 51540-3/ from SISBIO (Brazilian Institute of Environment and Natural Resources).

\section{References}

Alfaro ME, Holder MT (2006) The posterior and the prior in Bayesian phylogenetics. Annual Review of Ecology, Evolution, and Systematics 37: 19-42. https://doi.org/10.1146/ annurev.ecolsys.37.091305.110021

Benzaquem DC, Oliveira C, da Silva Batista J, Zuanon J, Porto JIR (2015) DNA Barcoding in Pencilfishes (Lebiasinidae: Nannostomus) Reveals Cryptic Diversity across the Brazilian Amazon. PLoS ONE 10(2): e0112217. https://doi.org/10.1371/journal. pone.0112217

Bragança PHN, Ottoni FP, Rangel-Pereira FS (2015) Hyphessobrycon ellisae, a new species from northeastern Brazil (Teleostei: Characidae). Ichthyological Exploration of Freshwaters 26(3): 255-262. http://pfeil-verlag.de/wp-content/uploads/2016/07/ief26_3_07.pdf

Carvalho FR (2011) Sistemática de Hyphessobrycon Durbin, 1908 (Ostariophysi: Characidae) PhD thesis, Porto Alegre, Brasil: Universidade Federal do Rio Grande do Sul. 
Carvalho FR, Malabarba LR (2015) Redescription and osteology of Hyphessobrycon compressus (Meek) (Teleostei: Characidae), type species of the genus. Neotropical Ichthyology 13(3): 513-540. https://doi.org/10.1590/1982-0224-20140173

Carvalho FR, Cabeceira FG, Carvalho LN (2017) New species of Hyphessobrycon from the Rio Teles Pires, Rio Tapajós basin, Brazil (Ostariophysi, Characiformes). Journal of Fish Biology 91(3): 750-763. https://doi.org/10.1111/jfb.13362

Castro-Paz FP, Batista JdS, Porto JIR (2014) DNA Barcodes of Rosy Tetras and Allied Species (Characiformes: Characidae: Hyphessobrycon) from the Brazilian Amazon Basin. PLoS ONE 9(5): e98603. https://doi.org/10.1371/journal.pone.0098603

Costa WJEM, Amorim PF (2011) A new annual killifish species of the Hypsolebias flavicaudatus complex from the São Francisco River basin, Brazilian Caatinga (Cyprinodontiformes: Rivulidae). Vertebrate Zoology 61(1): 99 -104.

Costa WJEM, Amorim PF, Aranha GN (2014) Species limits and DNA barcodes in Nematolebias, a genus of seasonal killifishes threatened with extinction from the Atlantic Forest of south-eastern Brazil, with description of a new species (Teleostei: Rivulidae). Ichthyological Exploration of Freshwaters 24(3): 225-236.

Costa WJEM, Géry J (1994) Two new species of the genus Hyphessobrycon (Characiformes: Characidae) from the rio xingú basin, Central Brazil. Revue Française d'Aquariologie Herpétologie 20: 71-76.

Costa WJEM, Amorim PF, Mattos JLO (2012) Species delimitation in annual killifishes from the Brazilian Caatinga, the Hypsolebias flavicaudatus complex (Cyprinodontiformes: Rivulidae): implications for taxonomy and conservation. Systematics and Biodiversity 10(1): 71-91. https://doi.org/10.1080/14772000.2012.664177

Costa WJEM, Cheffe MM, Amorim PF (2017) Two new seasonal killifishes of the Austrolebias adloffi group from the Lagoa dos Patos basin, southern Brazil (Cyprinodontiformes: Aplocheilidae). Vertebrate Zoology 67(2): 139 -149.

Darriba D, Taboada GL, Doallo R, Posada D (2012) jModelTest 2: more models, new heuristics and parallel computing. Nature Methods 9(8): 772. https://doi.org/10.1038/ nmeth.2109

Davis JI, Nixon KC (1992) Populations, genetic variation, and the delimitation of phylogenetics species. Systematic Biology 41(4): 421-435. https://doi.org/10.1093/sysbio/41.4.421

Dayrat B (2005) Towards integrative taxonomy. Biological Journal of the Linnean Society 85(3): 407-415. https://doi.org/10.1111/j.1095-8312.2005.00503.x

de Queiroz K (2005) Different species problems and their resolution. BioEssays 27(12): 1263-1269. https://doi.org/10.1002/bies.20325

de Queiroz K (2007) Species concepts and species delimitation. Systematic Biology 56(6): 879-886. https://doi.org/10.1080/10635150701701083

Eigenmann CH (1917) The American Characidae, Part I. Memoirs of the Museum of Comparative Zoology 43(1): 1-102.

Fink W, Weitzman S (1974) The so called Cheirodontin fishes of Central America with descriptions of two new species (Pisces: Characidae). Smithsonian Contributions to Zoology 172: 1-45. https://doi.org/10.5479/si.00810282.172 
García-Alzate CA, Román-Valencia C, Taphorn DC (2008a) Hyphessobrycon oritoensis (Characiformes: Characidae), a new species from the Putumayo river drainage, Colombian Amazon. Zootaxa 1813: 42-50. https://doi.org/10.5281/zenodo.182839

García-Alzate CA, Román-Valencia C, Taphorn DC (2008b) Revision of the Hyphessobrycon heterorhabdus group (Teleostei: Characiformes: Characidae), with description of two new species of Venezuela. Vertebrate Zoology 58(2): 139-157.

García-Alzate CA, Román-Valencia C, Taphorn C (2013) Una nueva especie de Hyphessobrycon (Characiformes: Characidae) de la cuenca del río Telembí, vertiente sur del Pacífico, Colombia. Revista de Biología Tropical 61(1): 181-192. https://doi.org/10.15517/rbt.v61i1.10944

García-Alzate CA, Urbano-Bonilla A, Taphorn DC (2017) A new species of Hyphessobrycon (Characiformes, Characidae) from the upper Guaviare River, Orinoco River Basin, Colombia. ZooKeys 668: 123-138. https://doi.org/10.3897/zookeys.668.11489

Géry J (1961). Three new South-American characids. Tropical Fish Hobbyist 9(9): 26-46.

Géry J (1977) Characoids of the world - TFH-publications, Neptune City Inc., 672 pp.

Géry J, Uj A (1987) Ein neuer tetra (Characoidea, Characidae, Tetragonopterinae) aus dem unteren Amazonasgebiet: Hyphessobrycon werneri n. sp. Aquarien und Terrarien-Zeitschrift 40(12): 546-550.

Goldstein PZ, DeSalle R (2010) Integrating DNA barcode data and taxonomic practice: determination, discovery, and description. BioEssays 33(2): 135-147. https://doi.org/10.1002/ bies. 201000036

Hebert PDN, Cywinska A, Ball SL, deWaard JR (2003a) Biological identifications through DNA barcodes. Proceedings of the Royal Society B 270(1512): 313-321. https://doi.org/10.1098/ rspb.2002.2218

Hebert PDN, Ratnasingham S, Waard JR (2003b) Barcoding animal life: cytochrome c oxidase subunit 1 divergences among closely related species. Proceedings of the Royal Society B 270(1): 96-99. https://doi.org/10.1098/rsbl.2003.0025

Hebert PD, Penton EH, Burns JM, Janzen DH, Hallwachs W (2004a) Ten species in one: DNA barcoding reveals cryptic species in the neotropical skipper butterfly Astraptes fulgerator. Proceedings of the National Academy of Sciences 101(41):14812-14817. https://doi.org/10.1073/ pnas.0406166101

Hebert PDN, Stoeckle MY, Zemlak TS, Francis CM (2004b) Identification of birds through DNA barcodes. PLoS Biology 2(10): e312. https://doi.org/10.1371/journal.pbio.0020312

Hein G (2009) Hyphessobrycon pando sp. n., a new rosy tetra from northern Bolivia (Teleostei, Characiformes, Characidae). Bulletin of Fish Biology 10(1/2): 1-10.

Huelsenbeck JP, Ronquist F (2001) Mr. Bayes: Bayesian inference of phylogenetic trees. Bioinformatics 17(8): 754-755. https://doi.org/10.1093/bioinformatics/17.8.754

Kearse M, Moir R, Wilson A, Stones-Havas S, Cheung M, Sturrock S, Buxton S, Cooper A, Markowitz S, Duran C, Thierer T, Ashton B, Meintjes P, Drummond A (2012) Geneious Basic: an integrated and extendable desktop software platform for the organization and analysis of sequence data. Bioinformatics 28(12): 1647-1649. https://doi.org/10.1093/bioinformatics/bts199

Kimura M (1980) A simple method for estimating evolutionary rates of base substitutions through comparative studies of nucleotide sequences. Journal of Molecular Evolution 16(2): 111-120. https://doi.org/10.1007/BF01731581 
Lima FCT, Pires THS, Ohara WM, Jerep FC, Carvalho FR, Marinho MMF, Zuanon J (2013) Characidae. In: Queiroz LJ, Torrente-Vilara G, Ohara WM, Pires THS, Zuanon J, Dória CRC (Eds). Peixes do rio Madeira. 1 ed. São Paulo, Dialeto Latin American Documentary 1: 213-395.

Marinho MMF, Dagosta FCP, Camelier P, Oyakawa OT (2016) A name for the 'blueberry tetra', an aquarium trade popular species of Hyphessobrycon Durbin (Characiformes, Characidae), with comments on fish species descriptions lacking accurate type locality. Journal of Fish Biology 89(1): 510-521. https://doi.org/10.1111/jfb.12991

Mattos JLO, Costa WJEM, Santos ACA (2015) Geophagus diamantinensis, a new species of the G. brasiliensis species group form Chapada Diamantina, north-eastern Brazil (Cichlidae: Geophagini). Ichthyological Exploration of Freshwaters 26(3): 209-220.

Miquelarena AM, López HL (2006) Hyphessobrycon togoi, a new species from the La Plata basin (Teleostei: Characidae) and comments about the distribution of the genus in Argentina. Revue Suisse de Zoologie 113(4): 817-828. https://doi.org/10.5962/bhl.part.80378

Moreira CR, Lima FCT (2017) Two new Hyphessobrycon (Characiformes: Characidae) species from Central Amazon basin, Brazil. Zootaxa 4318(1): 123-134. https://doi.org/10.11646/ zootaxa.4318.1.5

Mirande M (2010) Phylogeny of the family Characidae (Teleostei: Characiformes): from characters to taxonomy. Neotropical Ichthyology 8(3): 385-568. https://doi.org/10.1590/ S1679-62252010000300001

Ohara WM, Lima FCT, Barros BS (2017) Hyphessobrycon petricolus, a new species of tetra (Characiformes: Characidae) from the rio Madeira basin, Mato Grosso, Brazil. Zootaxa 4221(2): 242-250. https://doi.org/10.11646/zootaxa.4221.2.8

Oliveira C, Avelino GS, Abe KT, Mariguela TC, Benine RC, Ortí G, Vari RP, Castro RMC (2011) Phylogenetic relationships within the speciose family Characidae (Teleostei: Ostariophysi: Characiformes) based on multilocus analysis and extensive ingroup sampling. BMC Evolutionary Biology 11: 275. https://doi.org/10.1186/1471-2148-11-275

Padial JM, Miralles A, De la Riva I, Vences M (2010) The integrative future of taxonomy. Frontiers in Zoology 7: 16. https://doi.org/10.1186/1742-9994-7-16

Planquette P, Keith P, Le Bail PY (1996) Atlas des Poissons d'eau douce de Guyane. Tome 1. Collection du patrimoine naturel. Biotope/Publications scientifiques du MNHN, Paris, $421 \mathrm{pp}$.

Sabaj-Pérez MH (Ed.) (2016) Standard symbolic codes for institutional resource collections in herpetology and ichthyology, an online reference. Version 6.5 (16 August 2016). American Society of Ichthyologists and Herpetologists, Washington, D.C. Electronically accessible. http://www.asih.org/ [Accessed 29 jan 2018]

Tamura K, Peterson D, Peterson N, Stecher G, Nei M, Kumar S (2011) Mega 5: Molecular Evolutionary Genetic Analysis Using Maximum Likelihood. Evolutionary Distanceand Maximum Parsimony Methods. Molecular Biology and Evolution 28(10): 2731-2739. https://doi.org/10.1093/molbev/msr121

Roxo FF, Oliveira C, Zawadzki, CH (2012) Three new species of Neoplecostomus (Teleostei: Siluriformes: Loricariidae) from the Upper Rio Paraná basin of southeastern Brazil. Zootaxa 3233: 1-21. 
Taylor W, Van Dyke G (1985) Revised procedures for staining and clearing small fishes and other vertebrates for bone and cartilage study. Cybium 9: 107-119.

Teixeira TF, Netto-Ferreira AL, Birindelli JLO, Sousa LM (2015) Two new species of Hyphessobrycon (Characiformes: Characidae) from the headwaters of the Tapajós and Xingu River basins, Pará, Brazil. Journal of Fish Biology 88(2): 459-476. https://doi.org/10.1111/jfb.12803

Teletchea F (2009) Molecular identification methods of fish species: reassessment and possible applications. Reviews in Fish Biology and Fisheries 19: 265-293. https://doi.org/10.1007/ s11160-009-9107-4

Thompson JD, Higgins DG, Gibson TJ (1994) CLUSTAL W: improving the sensitivity of progressive multiple sequence alignment through sequence weighting, position-specific gap penalties and weight matrix choice. Nucleic Acids Research 22(22): 4673-4680. https://doi.org/10.1093/nar/22.22.4673

Villa-Verde L, Lazzarotto H, Lima SMQ (2012) A new glanapterygine catfish of the genus Listrura (Siluriformes: Trichomycteridae) from southeastern Brazil, corroborated by morphological and molecular data. Neotropical Ichthyology 10(3): 527-538. https://doi.org/10.1590/S167962252012000300005

Ward RD, Zemlak TS, Innes BH, Last PR, Hebert PDN (2005) DNA barcoding Australia’s fish species. Philosophical Transactions of the Royal Society of London B, Biological Sciences 360(1462): 1847- 1857. https://doi.org/10.1098/rstb.2005.1716

Weitzman SH (1962) The osteology of Brycon meeki, a generalized characid fish, with an osteological definition of the family. Stanford Ichthyological Bulletin 8(1): 3-77.

Weitzman SH, Palmer L (1997) A new species of Hyphessobrycon (Teleostei: Characidae) from the Neblina region of Venezuela and Brazil, with comments on the putative 'rosy tetra clade'. Ichthyological Exploration of Freshwaters 7(3): 209-242.

Wiens JJ, Penkrot TA (2002) Delimiting species using DNA and Morphological variation and discordant limitis in spiny lizards (Sceloporus). Systematic biology 51(1): 69-91. https://doi.org/10.1080/106351502753475880

Zarske A (2008) Hyphessobrycon khardinae sp. n. - ein neuer Blutsalmler aus Brasilien (Teleostei: Characiformes: Characidae). Vertebrate Zoology 58(1): 5-13.

Zarske A (2014) Zur Systematik einiger Blutsalmler oder "Rosy Tetras" (Teleostei: Ostariophysi: Characidae). Vertebrate Zoology 64(2): 139-167. 